\title{
Relationship between polymorphisms in beta -2 adrenergic receptor gene and ischemic stroke in North Indian Population: a hospital based case control study
}

\author{
Amit Kumar $^{1 *}$, Manjari Tripathi ${ }^{1}$, Madakasira Vasantha Padma Srivastava', Subbiah Vivekanandhan ${ }^{2}$ \\ and Kameshwar Prasad ${ }^{1 *}$
}

\begin{abstract}
Background: Stroke is a multi-factorial disease and influenced by both genetic and environmental factors. The purpose of the present case control study was to check the relationship between beta- 2 adrenergic receptor (ADRB2) polymorphism and ischemic stroke in North Indian Population.

Methods: In a hospital based case control study, patients with ischemic stroke and control subjects from outpatient department and neurology ward of All India Institute of Medical Sciences New Delhi. Genotyping was performed by using Polymerase chain reaction-Restriction fragment length polymorphism. Frequency distributions of genotypes and alleles were compared between cases and controls using multivariate logistic regression.

Results: In this study, 224 patients and 224 age-and sex-matched control subjects were recruited. Mean age of cases and controls were $53.9 \pm 13.4$ and $53.6 \pm 12.9$ years respectively. Multivariate logistic regression analysis showed an independent association between GIn27Glu polymorphism and large vessel stroke (LVD) under a recessive model of inheritance (OR 3.9; 95\% Cl 1.3 to 11). An age-stratified analysis, suggested independent association between Gln27Glu polymorphism and ischemic stroke, large vessel disease and small vessel disease stroke who had onset of disease at an older age.

Conclusions: The findings of the present study suggest that GIn27Glu polymorphism of the ADRB2 gene may confer higher risk of large vessel disease stroke in a North Indian population. Prospective studies with larger sample size are required for independent validation.
\end{abstract}

\section{Background}

Stroke is the second most common cause of death after ischemic heart disease [1], but, it ranks first in the Asian regions that have the highest population in the world [2]. There are 16.9 million incident stroke cases worldwide, twice as many stroke survivors, and 5.9 million deaths from stroke [2]. Incidence of stroke in South Asian countries have increased by more than $100 \%$ while this is deceased by $42 \%$ in developed European courtiers in last four decade [3]. World Health Organisation estimates suggest

\footnotetext{
*Correspondence: amits52003@gmail.com; kp0704@gmail.com ${ }^{1}$ Department of Neurology, Room No. 704, Neurosciences Centre, All India Institute of Medical Sciences, Ansari Nagar, New Delhi, India Full list of author information is available at the end of the article
}

that by 2050, 80 percent of stroke cases in the world would occur in low and middle income countries, mainly India and China [4].

Stroke is a multifactorial, polygenic disorder, influenced by both environmental and genetic factors. There are several risk factors has been discovered for stroke, such as hypertension, diabetes, smoking, dyslipidemia etc., however these risk factors do not explain why some individual are more susceptible to these environmental determinants in comparison to others with same given risk factors [5]. A growing body of evidence, suggesting that genetic variant may predispose to developing stroke [6]. The beta-2 adrenergic receptor, coded by an intronless gene on the long arm of chromosome 5q31-32 (Figure 1) and found 


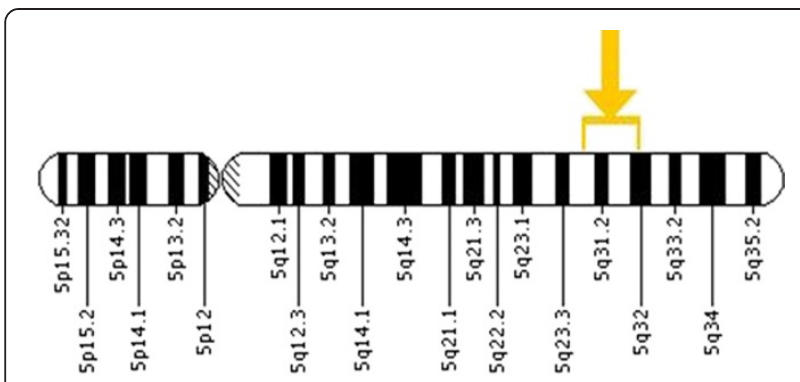

Figure 1 Location of beta-2 receptor in chromosome 5q31-32.

in multiple tissues (Table 1). It is members of the superfamily of $\mathrm{G}$ protein-coupled receptors that generally modulate action of catecholamine by an increase in level of secondary messenger cyclic AMP. It has been shown that agonist-independent, G-protein coupled receptor activity regulates anterior-posterior targeting of olfactory sensory neurons [7]. Reduced expression of beta- 2 adrenergic receptor contributes to the age- related deterioration of glucose tolerance [8]. It is broadly recognized that the beta-blocker therapy shows better response in younger patients than hospitalized senescent patients [9]. Cathecolamine-induced adenylate cyclase activity has been shown to decrease during ageing in human lymphocytes $[10,11]$. The age-related deterioration in betaadrenergic receptor function and subsequent cyclic AMP generation [12] that is a common factor underlying atherosclerosis, vascular insufficiency and hypertension [13] and these mechanisms are believed to confer increased risk for cardiovascular and cerebrovascular diseases [14].

\begin{tabular}{|c|c|c|c|c|}
\hline Subtype & $\begin{array}{l}\text { Tissue } \\
\text { distribution }\end{array}$ & Functions & $\begin{array}{l}\text { Gene } \\
\text { localization }\end{array}$ & $\begin{array}{l}\text { Common } \\
\text { functional } \\
\text { variants }\end{array}$ \\
\hline \multirow[t]{10}{*}{ BAR-2 } & $\begin{array}{l}\text { Lung, } \\
\text { Brochial }\end{array}$ & Bronchodilation & $5 q 31-q 32$ & Arg16Gly \\
\hline & $\begin{array}{l}\text { Vascular } \\
\text { smooth } \\
\text { muscle }\end{array}$ & Vasodialation & & Gln27Glu \\
\hline & Heart & $\begin{array}{l}\text { Positively inotropic } \\
\text { and chronotropic }\end{array}$ & & \\
\hline & Uterus & Relaxation & & \\
\hline & Bladder & Relaxation & & \\
\hline & Adipocytes & Lipolysis & & \\
\hline & Eye & $\begin{array}{l}\text { Increase aqueous } \\
\text { humor }\end{array}$ & & \\
\hline & Liver & Glycogenolysis & & \\
\hline & $\begin{array}{l}\text { Skeletal } \\
\text { Muscle }\end{array}$ & Glycogenolysis & & \\
\hline & $\begin{array}{l}\text { Sympathetic } \\
\text { terminal }\end{array}$ & $\begin{array}{l}\text { Nor-epinephrine } \\
\text { release }\end{array}$ & & \\
\hline
\end{tabular}

Abbreviation: BAR beta adrenergic receptor.
Cyclic AMP is also a possible target for prevention and treatment of atherosclerosis [15]. It is reported in the recent year that these polymorphisms are related to many kinds of clinical diseases such as asthma, hypertension, diabetes, heart diseases [16]. In the present study, we examined the relationship of Arg16Gly and Gln27Glu polymorphisms of beta- 2 adrenergic receptor (Figure 2) as a risk factor for ischemic stroke in the North India in order to facilitate early diagnosis of the susceptible population and prevention of ischemic stroke.

\section{Methods}

During this study, 224 patients with ischemic stroke and 224 control subjects were enrolled from the ward and outpatient department of Neurology, All India Institute of Medical Sciences (AIIMS), New Delhi, India from the period of February 2010 to April 2012. Ischemic stroke was defined as rapidly developing clinical signs of focal (or global) disturbance of cerebral function, with symptoms lasting more than 24 hours or longer or leading to death, with no apparent cause other than of vascular origin [17]. Stroke is a heterogeneous phenotype, therefore, analysis based on specific stroke cause in important in genetic association studies, therefore, we used TOAST criteria to determine stroke aetiology [18], which include large vessel stroke which occurs usually due to atherosclerosis or occlusion of major brain artery or branch cortical artery and small vessel stroke which occur due to the involvement of small perforating end arteries within the brain. All subjects underwent standardized clinical evaluations. The study was approved by the All India Institute of Medical Sciences, New Delhi ethics committee (Ref No. P-02/06.10.2008). Informed consent was obtained from each patient/control subject or from the relatives or a legal representative in the case of critically disabled patients. Inclusion and exclusion criteria for cases and control subjects are same as earlier published article by our team [19]. Definitions of variables are same as in the published study [5].

\section{Sample size}

Sample size calculation was based on parameters of the study reported by Stanzione et al. [20], on beta-adrenergic receptor polymorphism in ischemic stroke in which prevalence for the beta-adrenergic receptor variant Glu27Glu genotype was 0.32 in control group and odds ratio for this polymorphism was 1.68 . Assuming $80 \%$ power and $5 \%$ alpha, with one control per case, we obtained estimated minimum sample size were 212. 224 patients and 224 controls were included in this study to compensate for any loss of sample.

\section{Genomic DNA extraction}

Genomic DNA was isolated by conventional Phenol Chloroform Method. DNA concentrations were estimated 


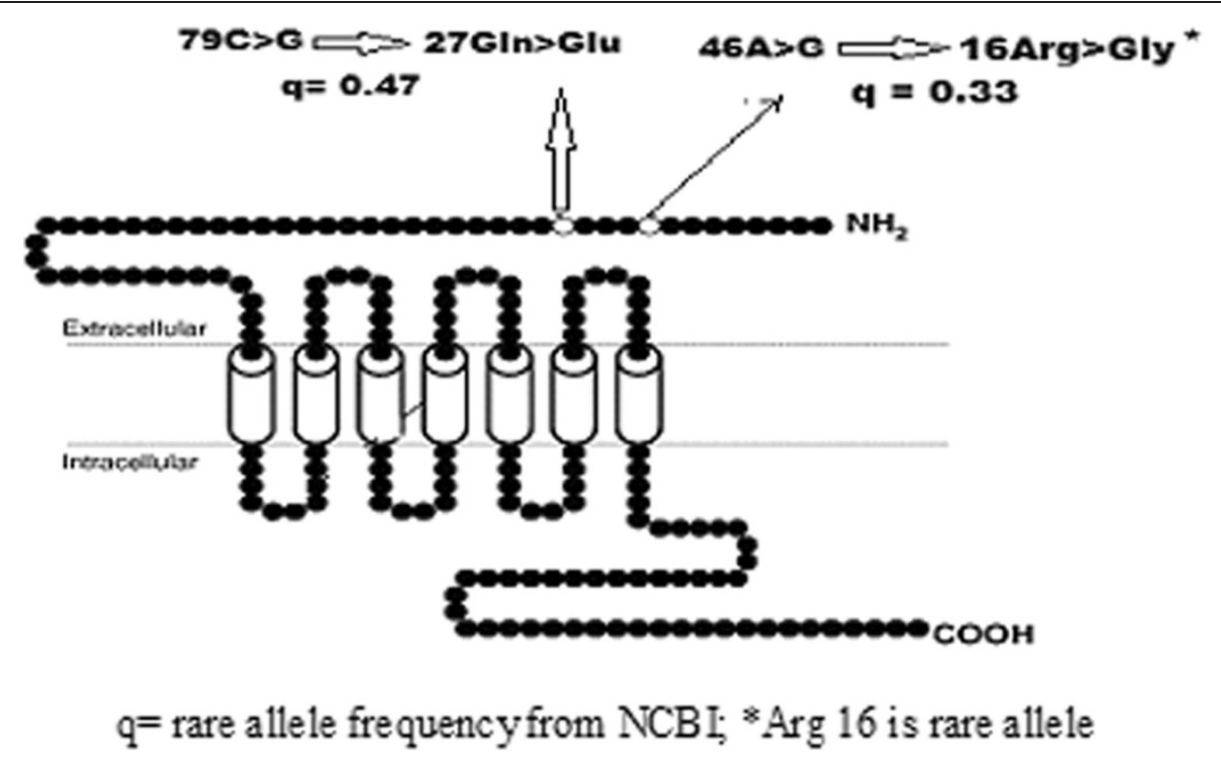

Figure 2 Localization and characterization beta-2, adrenergic receptor polymorphism studied.

by measuring the absorbance at 260 and $280 \mathrm{~nm}$ using a nanodrop spectrophotometer (Gene Quant, Pharmacia, USA) and its quality was assessed by the A260/A280 ratio. DNA samples with a $260 / 280$ ratio ranging from 1.5 to 1.8 were processed for PCR amplification.

\section{Detection of gene polymorphisms}

Genotyping: Primers used for the amplification of Arg16Gly polymorphism of beta-2 adrenergic receptor is: forward: 5'-CTTCTTGCTGGCACGCAAT -3' reverse: 5'-C CAGTGAAGTGATGAAGTAGTTGG -3', (PCR product length was $201 \mathrm{bp}$, restriction enzyme BsrD1; Ferments; $2.5 \mathrm{U}$ for $6 \mathrm{~h}$ at $37^{\circ} \mathrm{C}$ ). For determination of Gln27Glu polymorphism, primer used were forward 5'-GAATGAG GCTTCCAGGCGTC-3' reverse 5'- GGCCCATGACC AGATCAGCA-3' (PCR product length was 356 bp; restriction enzyme FNu4HI Fermentas; $0.5 \mathrm{U}$ for $6 \mathrm{~h}$ at $37^{\circ} \mathrm{C}$ ). The restriction products were separated by electrophoresis in $2.5 \%$ agarose gels and visualized in UV light. Gel Images were documented by using gel doc.

\section{Statistical analyses}

Allele frequencies were compared using the Chi square test. The conditional logistic regression model was used to estimate Odds ratio (OR) and 95\% confidence intervals (CIs) for association of beta-1 receptor polymorphisms with ischemic stroke. Multivariate logistic regression was used to control the confounding effect of demographic and risk factor variables. Tests were considered significant at $P<0.05$. The chi square test was used to determine the frequency distribution of genotypes, were in accordance with Hardy-Weinberg equilibrium (HWE). Data were analyzed using the SPSS statistical package, version 17.0 (SPSS, Chicago, IL, USA).

Table 2 Demographic and risk factors variables of Ischemic stroke patients and controls

\begin{tabular}{|c|c|c|c|c|c|}
\hline S.No & Variables & Case & Control & Unadjusted OR (95\% CI), p value & ${ }^{*}$ Adjusted OR $(95 \% \mathrm{CI})$, p value \\
\hline 1 & ${ }^{a}$ Age $\pm S D$ (years) & $53.9 \pm 3.4$ & $53.6 \pm 12.9$ & Matched & Matched \\
\hline 2 & Male/Female & $183 / 41$ & $183 / 41$ & Matched & Matched \\
\hline 3 & Hypertension n (\%) & $138(62 \%)$ & $48(21 \%)$ & $5.8(3.8$ to 8.8$),<0.001$ & $6.6(3.4$ to 12.9$),<0.001$ \\
\hline 4 & Smoking n (\%) & $98(44 \%)$ & $53(24 \%)$ & $2.4(1.6$ to 3.6$),<0.001$ & 2.8 (1.5 to 5.2$), 0.001$ \\
\hline 5 & Diabetes n (\%) & $67(31 \%)$ & $35(16 \%)$ & 2.4 (1.5 to 3.8), 0.001 & 1.5 (0.85 to 2.8$), 0.15$ \\
\hline 6 & Migraine n (\%) & $20(9 \%)$ & $15(6 \%)$ & 1.3 (0.67 to 2.8), 0.37, & NA \\
\hline 7 & Dyslipidemia n (\%) & $96(43 \%)$ & $37(17 \%)$ & $3.6(2.3$ to 5.7$),<0.001$ & $3.8(1.9$ to 7.7$),<0.001$ \\
\hline 8 & FHS n (\%) & $48(21.5)$ & 15(6.9) & 3.7 (2 to 6.8 ), $<0.001$ & $5.2(2.3$ to 11.5$),<0.001$ \\
\hline
\end{tabular}

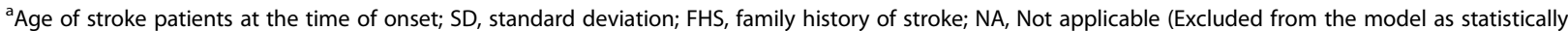
not significant). 
Table 3 Association between Arg16Gly and Gln27Glu polymorphisms of beta -2 adrenergic receptor and Ischemic stroke

\begin{tabular}{|c|c|c|c|c|c|c|c|c|c|c|c|c|}
\hline \multirow{2}{*}{$\begin{array}{l}\text { Polymorphism } \\
\text { Arg16Gly }\end{array}$} & \multirow[t]{2}{*}{$\mathrm{N}$} & \multirow[t]{2}{*}{ Sample } & \multicolumn{3}{|c|}{$\begin{array}{l}\text { Genotype } \\
\text { distribution (\%) }\end{array}$} & \multirow{2}{*}{$\begin{array}{l}\text { HWE } \\
\text { P value }\end{array}$} & \multirow{2}{*}{$\begin{array}{l}\text { Recessive } \\
\text { Adjusted } \\
\text { OR }[95 \% \mathrm{Cl}] \\
\text { P value }\end{array}$} & \multirow{2}{*}{$\begin{array}{l}\text { Dominant } \\
\text { Adjusted } \\
\text { OR }[95 \% \mathrm{Cl}] \\
\text { P value }\end{array}$} & \multirow[t]{2}{*}{ Sample } & \multicolumn{2}{|c|}{$\begin{array}{l}\text { Allele } \\
\text { distribution (\%) } \\
\end{array}$} & \multirow{2}{*}{$\begin{array}{l}\text { OR }[95 \% \mathrm{Cl}] \\
\text { P value }\end{array}$} \\
\hline & & & Arg/Arg & Arg/Gly & Gly/Gly & & & & & Arg & Gly & \\
\hline & 224 & IS & 21 & 53 & 26 & 0.39 & 1.5 & 1.5 & IS & 47 & 53 & 1.3 [0.7 to 2.3$]$ \\
\hline & 224 & Controls & 28 & 52 & 20 & 0.43 & [0.76 to 3.2$]$ & [0.74 to 3.3$]$, & Control & 54 & 46 & 0.32 \\
\hline & & & & & & & 0.21 & 0.23 & & & & \\
\hline & 76 & LVD & 20 & 55 & 25 & 0.34 & 1.2 & 0.97 & LVD & 47 & 53 & 1.3 [0.7 to 2.3] \\
\hline & 224 & Control & 28 & 52 & 20 & 0.43 & [0.21 to 7.6,$]$ & [0.07 to 13$],$ & Control & 54 & 46 & 0.32 \\
\hline & & & & & & & 0.78 & 0.98 & & & & \\
\hline & 78 & SVD & 19 & 50 & 31 & 0.88 & 2.9 & 2.4 & SVD & 44 & 56 & 1.4 [0.8 to 2.6], \\
\hline & 224 & Control & 28 & 52 & 20 & 0.43 & [0.71 to 12$]$ & [0.43 to 13$]$ & Control & 54 & 46 & 0.15 \\
\hline & & & & & & & 0.13 & 0.31 & & & & \\
\hline Gln27Glu & & & $\mathrm{Gln} / \mathrm{Gln}$ & Gln/Glu & Glu/Glu & & & & & Gln & Glu & \\
\hline & 224 & IS & 44 & 40 & 16 & 0.07 & 2.8 & 1.5 & IS & 64 & 36 & $1.6[0.91$ to 3.1$]$ \\
\hline & 224 & Controls & 55 & 39 & 6 & 0.59 & [0.98 to 8.1$]$ & [0.91 to 2.7], & Control & 75 & 25 & 0.09 \\
\hline & & & & & & & 0.05 & 0.10 & & & & \\
\hline & 76 & LVD & 47 & 35 & 18 & 0.04 & 3.9 & 1.5 & LVD & 64 & 36 & $1.6[0.91$ to 3.1$]$ \\
\hline & 224 & Control & 55 & 39 & 6 & 0.59 & [1.3 to 11$]$ & [0.81 to 2.9$]$, & Control & 75 & 25 & 0.09 \\
\hline & & & & & & & 0.01 & 0.18 & & & & \\
\hline & 78 & SVD & 42 & 45 & 13 & 0.87 & 0.97 & 1.4 & SVD & 65 & 35 & 1.6 [ 0.87 to 2.9$]$, \\
\hline & 224 & Control & 55 & 39 & 6 & 0.59 & [0.15 to 6.1$]$ & [0.44 to 5$]$ & Control & 75 & 25 & 0.12 \\
\hline & & & & & & & 0.98 & 0.51 & & & & \\
\hline
\end{tabular}

Abbreviations: IS ischemic stroke, OR odds ratio, Cl confidence interval, LVD large vessel stroke, SVD small vessel stroke.

\section{Results}

Demographic and risk factor variables in cases and controls are given in (Table 2). Multivariate analysis did not show a significant association between Arg16Gly polymorphism and ischemic stroke (Table 3 and Additional file 1: Table S1). Analysis stratified by hypertension and age showed weak associations of Arg16Gly polymorphism among some of subgroups (Additional file 1: Table S2). Borderline significance was observed between Gln27Glu polymorphism of beta-2 AR and ischemic stroke (OR, 2.8; $95 \% \mathrm{CI}, 0.98$ to $8.1 ; P=0.05)$ under recessive model of

Table 4 Haplotype frequencies of beta-2 adrenergic receptor Arg16Gly and GIn27Glu polymorphisms

\begin{tabular}{llllc}
\hline Haplotype & Case $\mathbf{n}(\%)$ & Control n (\%) & OR (95\% CI) & $\boldsymbol{P}$ Value \\
\hline Arg16-Gln27 & $115(25.7)$ & $205(45.7)$ & Reference & \\
Arg16-Glu27 & $97(21.5)$ & $38(8.5)$ & $4.5(2.9$ to 7$)$ & $<0.001$ \\
Gly16-Glu27 & $172(38.4)$ & $129(28.8)$ & $2.3(1.7$ to 3.2) & $<0.001$ \\
Gly16-Gln27 & $64(14.4)$ & $76(17)$ & $1.5(1.001$ to 2.2) & 0.04 \\
Total & 448 & 448 & & \\
\hline
\end{tabular}

Abbreviations: OR odds ratio, Cl 95\% confidence interval, Gly Glycine, Arg Arginine, Glu Glutamic acid, Gln Glutamine. inheritance (Table 3). Distribution of genotypic and allelic frequencies of polymorphism at Gln27Glu (SNP 79 $\mathrm{C}>\mathrm{G}$ ) position of beta-2 adrenergic receptor gene in controls and ischemic stroke and its subtypes are given in Additional file 1: Table S3. Significant association was observed between Gln27Glu polymorphism and LVD stroke (OR, 3.9; 95\% CI, 1.3 to $11 ; P=0.01$ ) in adjusted analysis under the recessive model of inheritance (Table 3). Age stratified analysis, showed an independent significant association between Gln27Glu variant and risk of overall ischemic stroke, LVD stroke and SVD stroke, assuming both recessive and dominant model of inheritance only in the patients, those who had late onset ( $>50$ years) of disease (Additional file 1: Table S4). Individuals carrying haplotype Arg16-Glu27 were found to be 4.5 fold higher risk of ischemic stroke as compared to control (OR, 4.5; 95\% CI, 2.9 to 7). Gly16-Glu27 haplotype was significantly associated with risk of ischemic stroke (OR, 2.3; 95\% CI, 1.7 to 3.2 ) (Table 4).

\section{Discussion}

In this hospital based case control study, a common functional polymorphism at Gln27Glu position of beta-2 
Table 5 Frequency distribution of variant allele of Arg16Gly and GIn27Glu polymorphism in few of different ethnic regions

\begin{tabular}{|c|c|c|c|c|c|c|c|}
\hline \multirow[t]{3}{*}{ Study design } & \multirow[t]{3}{*}{ Year } & \multicolumn{2}{|c|}{ Allele frequency (\%) } & \multirow[t]{3}{*}{ Population } & \multirow{3}{*}{$\begin{array}{l}\text { Sample size } \\
\text { Case/control }\end{array}$} & \multirow[t]{3}{*}{ Condition } & \multirow[t]{3}{*}{ Reference } \\
\hline & & Gly16 & Glu27 & & & & \\
\hline & & Case/control & Case/control & & & & \\
\hline Case control & 1998 & NA & $0.43 / 0.36$ & Denmark & $156 / 205$ & Obesity & [21] \\
\hline Case control & 2006 & NA & $0.26 / 0.15$ & Saudi Arabia & $773 / 528$ & Coronary artery disease & [22] \\
\hline Case control & 2007 & $0.66 / 0.65$ & $0.57 / 0.48$ & Italy & $294 / 286$ & Stroke & {$[20]$} \\
\hline Case control & 2011 & $0.46 / 0.43$ & $0.17 / 0.14$ & Chinese & $238 / 265$ & Asthma & [23] \\
\hline Case control & 2012 & $0.49 / 0.39$ & $0.07 / 0.12$ & Malaysia & $50 / 50$ & Hypertension & [24] \\
\hline Case control & 2005 & $0.40 / 0.38$ & $0.43 / 0.41$ & California & $194 / 819$ & Myocardial infarction & [25] \\
\hline Cohort study & 2009 & 0.58 & 0.29 & Brazil & 501 & Heart Failure & [26] \\
\hline Meta-analysis & 2012 & $0.47 / 0.46$ & $0.48 / 0.17$ & Asian & $1097 / 844$ & $\begin{array}{l}\text { Chronic obstructive } \\
\text { pulmonary disease }\end{array}$ & [27] \\
\hline Meta-analysis & 2012 & $0.61 / 0.62$ & $0.41 / 0.40$ & Caucasian & $727 / 850$ & $\begin{array}{l}\text { Chronic obstructive } \\
\text { pulmonary disease }\end{array}$ & [27] \\
\hline Case control & 2012 & $0.60 / 0.65$ & $0.27 / 0.30$ & North Indian & $410 / 414$ & Asthma & {$[28]$} \\
\hline Case control & 2014 & $0.52 / 0.58$ & $0.47 / 0.23$ & North Indian & $106 / 106$ & Hemorrhagic Stroke & {$[29]$} \\
\hline Present study & 2014 & $0.53 / 0.46$ & $0.36 / 0.25$ & North Indian & $224 / 224$ & Ischemic Stroke & Present study \\
\hline
\end{tabular}

AR was found to be associated with more than threefold increased risk of LVD stroke.

The present study is the first study, up to the best of our knowledge, showing the association of Arg16Gly and Gln27Glu polymorphisms of beta-2 adrenergic receptor with ischemic stroke in Asian population. Frequency distribution of variant alleles of Arg16Gly and Gln27Glu polymorphisms of beta- 2 adrenergic receptors in our study are consistent with the other previously reported studies (Table 5).

In vitro studies have shown higher agonist induced desensitization for Gly16 variant in comparison to Arg16 variant after the administration of isoprenaline which is a nonselective beta adrenergic agonist [30]. In vitro study [31] has indicated that Glu27 variant produces a higher degree of responsiveness to adrenergic agonist with resistance to down regulation relative to wild type allele, however, strong linkage disequilibrium between codon 16 and codon 27 and there is greater probability that subjects who are carrying Glu27Glu genotype are mostly homozygous for Gly16 allele than Arg16 [32]. Our study also showed similar linkage disequilibrium. Gly16-Glu27 haplotype showed enhanced receptor down regulation after exposure to isoprenaline when compared with Arg16-Glu27 [30]. Due to strong linkage disequilibrium, it has been suggested that subject carrying Gly16-Glu27 haplotype may have greater down regulation and desensitization as compared to Arg16 allele [30,33]. Down regulation of this receptor may lead to decrease in concentration of cyclic AMP in the vascular smooth muscle, lungs, kidney, and sympathetic terminal. This decrease in cyclic AMP leads to modulation of atherosclerosis, recruitment of reactive oxygen species, and recruitment of circulating monocytes to the artery wall and their differentiation into macrophage foam cell, by controlling the expression of proinflammatory and anti-inflammatory interleukin [15]. By these mechanisms, beta- 2 adrenergic receptor gene polymorphisms might influence the genetic predisposition to ischemic stroke. Several studies have shown the independent association of Gln27Glu polymorphism of beta-2 adrenergic receptor gene polymorphism with a number of diseases like obesity [34,35], dyslipidemia [36], myocardial infarction [16], diabetes [37]. Few studies have addressed the association of beta- 2 receptor polymorphism with ischemic stroke and both positive and negative associations have been reported. A case control study, reported from Italy, indicated a positive association between Gln27Glu polymorphism and Ischemic stroke [20]. A previous study by Heckbert et al., failed to show significant association of beta-2 adrenergic receptor variant with the incidence of stroke [38]. A prospective cohort study included 25225 women showed that the different haplotypic combination of beta receptor gene variant did not affect the incidence of ischemic stroke in women [39]. A case control study reported by Zhao et al. did not find significant association of Gln27Glu polymorphism with risk of ischemic stroke, however, higher frequency of variant Glu27 allele in ischemic stroke patients $(0.11)$ than controls (0.07) has been observed [40]. In all the published case control studies (three), the frequency of the risk allele (Glu27) was higher in cases as compared to controls. Our study also indicated a significant association 
between Gln27Glu polymorphism and ischemic stroke associated with large vessel disease.

Hypertension is a most important and common risk factor for stroke. A meta-analysis published by Lou Y, et al., [41] showed significant association between Arg16Gly polymorphism and risk of hypertension under a dominant model in a subgroup of mixed African (OR, 1.18, 95\% CI, 1.01 to $1.87, \mathrm{P}=0.04$ ). This meta-analysis also indicated the significant association between Gln27Glu polymorphism and hypertension under a dominant model of inheritance (OR, 1.38; 95\% CI, 1.02 to 1.86) [41]. Other polymorphisms such as on gene CaMK4 (calcium/calmodulin-dependent kinase 4) which has a role in regulation of vascular tone also have been shown to be associated with hypertension [42]. A previous study has demonstrated that more than $85 \%$ patients with CHD have at least 1 of five modifiable risk factors (hypertension, diabetes, and hypercholesterolemia, smoking and family history) $[43,44]$. A previous study indicated that the $\mathrm{P}$ (A2) polymorphism is a genetic determinant of ischemic stroke in a high-risk hypertensive population [45]. Our analysis, stratified by hypertension indicates that Glu27 variant is associated with both the hypertensive and non-hypertensive stroke subjects and shows a similar pattern of associations in both the groups (Additional file 1: Table S4).

The age-related decline in beta-adrenergic receptor function and subsequent cyclic AMP generation [12] is a common factor underlying atherosclerosis, vascular insufficiency and hypertension [13]. A study has shown that age-associated decline in beta-adrenergic receptor sensitivity in the cardiovascular system [46]. Our agestratified analysis, showed significant associations of Gln27Glu polymorphism in only those patients who had onset of disease at late ( $>50$ years) stage. During old age conventional risk factors of stroke becomes more prevalent and it is possible that Glu27 variant may interact at later stages of age with other conventional risk factors that cause stroke.

In the present study, individuals who had Arg16-Glu27 haplotype were found to have a higher risk of ischemic stroke. This association shows the additive effects of both the alleles and may have enhanced combined impact of ischemic stroke risk. The present study suggests that Haplotype Gly16-Glu27 was most prevalent haplotype and significantly associated with risk of ischemic stroke. This is consistent with finding of the study reported by Stanzione et al. [20].

Studies have shown that there is a relationship between the effectiveness of beta-blocker treatment and beta adrenergic receptor polymorphism [47]. Further studies are required to check the significance of beta blocker treatment and stroke prevention in carrier of beta-adrenergic receptor polymorphism.

\section{Limitation of the study}

The sample size of the present study might not be large enough to detect small effects of low penetrance SNPs. Each susceptible polymorphism may only contribute to mild effect, thus the analysis of single SNP could be ambiguous by unstudied polymorphisms and environmental factors that influences the phenotype. Borderline deviation from HWE was observed in the distribution of genotypes in patients with LVD stroke. We cannot completely exclude the effects of residual confounding attributable to the measurement error in the assessment of confounding factors. In the present study, the numbers of male patients were more than double the number of female patients, which substantiates that results of this study may be applied to male ischemic stroke populations.

\section{Conclusion}

In conclusion, this study provides evidence that the presence of Arg16-Glu27 haplotype of beta-2 adrenergic receptor in the subjects might confer increased risk of developing ischemic stroke. Gln27Glu polymorphism may confer increased risk for developing stroke associated with large vessel. Identification of a subgroup of patients, who are carrier of beta-adrenergic receptor polymorphism, may have implication for planning their future treatment strategies. Prospective studies with larger sample size are required for independent validation.

\section{Additional file}

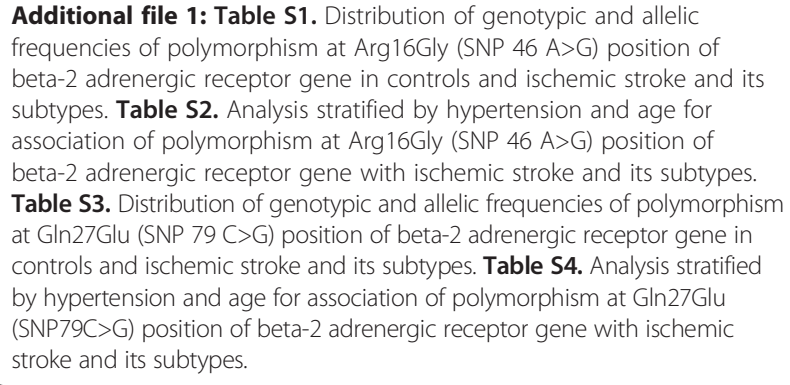

Competing interests

The authors declare that they have no competing interests.

\section{Authors' contributions}

AK has participated in the writing of manuscript, conception, design and conduct of the study. KP has participated in the design, analysis and

interpretation of data. MT, MVPS and SV have participated in the conception and design of the study. All authors read and approved the final manuscript.

\section{Acknowledgement}

Funding support of the study was obtained from the Indian Council of Medical Research, Government of India. 


\section{Author details}

'Department of Neurology, Room No. 704, Neurosciences Centre, All India Institute of Medical Sciences, Ansari Nagar, New Delhi, India. ${ }^{2}$ Department of Neurobiochemistry, All India Institute of Medical Sciences, New Delhi, India.

Received: 21 October 2013 Accepted: 13 June 2014

Published: 25 June 2014

\section{References}

1. World Health Organisation.int [internet]: WHO media centre. [Updated July 2013]. Available from: https://apps.who.int/infobase/Mortality.aspx.

2. Davis $S$, Norrving B: Organizational update: world stroke organization. Stroke J Cereb Circ 2014, 45(5):e84.

3. Feigin VL, Lawes CMM, Bennett DA, Barker-Collo SL, Parag V: Worldwide stroke incidence and early case fatality reported in 56 population-based studies: a systematic review. Lancet Neurol 2009, 8(4):355-369.

4. World Health Organisation.int [internet]: WHO media centre. [Updated July 2013]. Available from: https://apps.who.int/infobase/Indicators.aspx.

5. Kumar A, Sagar R, Kumar P, Sahu JK, Grover A, Srivastava AK, Vivekanandhan S, Prasad K: Identification of genetic contribution to ischemic stroke by screening of single nucleotide polymorphisms in stroke patients by using a case control study design. BMC Neurol 2013, 13(1):136.

6. Hassan A, Markus HS: Genetics and ischaemic stroke. Brain J Neurol 2000, 123(Pt 9):1784-1812

7. Nakashima A, Takeuchi H, Imai T, Saito H, Kiyonari H, Abe T, Chen M, Weinstein LS, Yu CR, Storm DR, Nishizumi H, Sakano H: Agonist-independent GPCR activity regulates anterior-posterior targeting of olfactory sensory neurons. Cell 2013, 154(6):1314-1325.

8. Santulli G, Lombardi A, Sorriento D, Anastasio A, Del Giudice C, Formisano P, Béguinot F, Trimarco B, Miele $C$, laccarino G: Age-related impairment in insulin release: the essential role of $\beta(2)$-adrenergic receptor. Diabetes 2012, 61(3):692-701.

9. Greenblatt DJ, Koch-Weser J: Adverse reactions to propranolol in hospitalized medical patients: a report from the Boston Collaborative Drug Surveillance Program. Am Heart J 1973, 86(4):478-484.

10. Krall JF, Connelly M, Tuck ML: Evidence for reversibility of age-related decrease in human lymphocyte adenylate cyclase activity. Biochem Biophys Res Commun 1981, 99(3):1028-1034.

11. Santulli G, laccarino G: Pinpointing beta adrenergic receptor in ageing pathophysiology: victim or executioner? Evidence from crime scenes. Immun Ageing A 2013, 10(1):10.

12. Schutzer WE, Mader SL: Age-related changes in vascular adrenergic signaling: clinical and mechanistic implications. Ageing Res Rev 2003 2(2):169-190.

13. Vu T-HT, Stamler J, Liu K, McDermott MM, Lloyd-Jones DM, Pirzada A, Garside DB, Daviglus ML: Prospective relationship of low cardiovascular risk factor profile at younger ages to ankle-brachial index: 39-year follow-upthe Chicago Healthy Aging Study. J Am Heart Assoc 2012, 1(6):e001545.

14. Iwamoto Y, Ohishi M, Yuan M, Tatara Y, Kato N, Takeya Y, Onishi M, Maekawa $Y$, Kamide K, Rakugi H: $\beta$-Adrenergic receptor gene polymorphism is a genetic risk factor for cardiovascular disease: a cohort study with hypertensive patients. Hypertens Res Off J Jpn Soc Hypertens 2011, 34(5):573-577.

15. Fantidis $P$ : The role of intracellular $3^{\prime} 5^{\prime}$-cyclic adenosine monophosphate (cAMP) in atherosclerosis. Curr Vasc Pharmacol 2010, 8(4):464-472.

16. Yilmaz A, Kaya MG, Merdanoglu U, Ergun MA, Cengel A, Menevse S: Association of beta- 1 and beta-2 adrenergic receptor gene polymorphisms with myocardial infarction. J Clin Lab Anal 2009, 23(4):237-243.

17. The World Health Organization: MONICA Project (monitoring trends and determinants in cardiovascular disease): a major international collaboration. WHO MONICA Project Principal Investigators. J Clin Epidemiol. 1988, 41(2):105-114.

18. Adams HP Jr, Bendixen BH, Kappelle LJ, Biller J, Love BB, Gordon DL, Marsh EE 3rd: Classification of subtype of acute ischemic stroke. Definitions for use in a multicenter clinical trial. TOAST. Trial of Org 10172 in Acute Stroke Treatment. Stroke J Cereb Circ. 1993, 24(1):35-41.

19. Kumar A, Vivekanandhan S, Srivastava A, Tripathi M, Padma Srivastava MV, Saini N, Kumar P, Prasad K: Association between angiotensin converting enzyme gene insertion/deletion polymorphism and ischemic stroke in north Indian population: a case-control study and meta-analysis. Neurol Res. 2014, 12:1743132814Y0000000335.
20. Stanzione R, Di Angelantonio E, Evangelista A, Barbato D, Marchitti S, Zanda B, Pirisi A, Quarta G, Volpe M, Rubattu S: Beta2-adrenergic receptor gene polymorphisms and risk of ischemic stroke. Am J Hypertens 2007 20(6):657-662.

21. Echwald SM, Sørensen TI, Tybjaerg-Hansen A, Andersen T, Pedersen O: Gln27Glu variant of the human beta2-adrenoreceptor gene is not associated with early-onset obesity in Danish men. Diabetes 1998, 47(10):1657-1658.

22. Abu-Amero KK, Al-Boudari OM, Mohamed GH, Dzimiri N: The Glu27 genotypes of the beta2-adrenergic receptor are predictors for severe coronary artery disease. BMC Med Genet. 2006, 7:31.

23. Fu W-P, Zhao Z-H, Zhong L, Sun C, Fang L-Z, Liu L, Zhang JQ, Wang L, Shu JK, Wang XM, Dai LM: Relationship between polymorphisms in the $5^{\prime}$ leader cistron, positions 16 and 27 of the adrenergic $\beta 2$ receptor gene and asthma in a Han population from southwest China. Respirol Carlton Vic 2011, 16(8):1221-1227.

24. Atia AE, Norsidah K, Nor Zamzila A, Rafidah Hanim M, Samsul D, Aznan MA Rashidah AR, Norlelawati AT: Preliminary study on association of beta2-adrenergic receptor polymorphism with hypertension in hypertensive subjects attending Balok Health Centre. Kuantan. Med J Malaysia. 2012, 67(1):25-30.

25. Zee RYL, Cook NR, Reynolds R, Cheng S, Ridker PM: Haplotype analysis of the beta 2 adrenergic receptor gene and risk of myocardial infarction in humans. Genetics 2005, 169(3):1583-1587.

26. Mansur AJ, Fontes RS, Canzi RA, Nishimura R, Alencar AP, de Lima ACP, Krieger JE, Pereira AC: Beta-2 adrenergic receptor gene polymorphisms Gln27Glu, Arg16Gly in patients with heart failure. BMC Cardiovasc Disord 2009, 9:50.

27. Niu L-M, Liang $Y, X u$ M, Zhang $Y-Y$, Zhang $Y$, He B: Effect of polymorphisms in the $\beta 2$-adrenergic receptor on the susceptibility and pulmonary function of patients with chronic obstructive pulmonary disease: a meta analysis. Chin Med J (Engl) 2012, 125(12):2213-2218.

28. Birbian N, Singh J, Jindal SK, Singla N: Association of $\beta(2)$-adrenergic receptor polymorphisms with asthma in a North Indian population. Lung 2012, 190(5):497-504.

29. Kumar A, Prasad K, Tripathi M, Padma Srivastava MV, Vivekanadhan S: Association of genetic polymorphisms at beta-adrenergic receptor with risk of intracerebral hemorrhagic stroke in North Indian population: A case control study. Neurol India 2014, 62:183-188.

30. Green SA, Turki J, Innis M, Liggett SB: Amino-terminal polymorphisms of the human beta 2-adrenergic receptor impart distinct agonist-promoted regulatory properties. Biochemistry (MosC) 1994, 33(32):9414-9419.

31. Dishy V, Sofowora GG, Xie HG, Kim RB, Byrne DW, Stein CM, Wood AJ: The effect of common polymorphisms of the beta2-adrenergic receptor on agonist-mediated vascular desensitization. N Engl J Med 2001, 345(14):1030-1035.

32. Dewar JC, Wheatley AP, Venn A, Morrison JF, Britton J, Hall IP: Beta2-adrenoceptor polymorphisms are in linkage disequilibrium, but are not associated with asthma in an adult population. Clin Exp Allergy $J$ Br Soc Allergy Clin Immunol 1998, 28(4):442-448.

33. Forleo C, Resta N, Sorrentino S, Guida P, Manghisi A, De Luca V, Romito R, lacoviello M, De Tommasi E, Troisi F, Rizzon B, Guanti G, Rizzon P, Pitzalis MV: Association of beta-adrenergic receptor polymorphisms and progression to heart failure in patients with idiopathic dilated cardiomyopathy. Am J Med 2004, 117(7):451-458.

34. Large V, Hellström L, Reynisdottir S, Lönnqvist F, Eriksson P, Lannfelt L, Arner P: Human beta-2 adrenoceptor gene polymorphisms are highly frequent in obesity and associate with altered adipocyte beta-2 adrenoceptor function. J Clin Invest 1997, 100(12):3005-3013.

35. Lange LA, Norris JM, Langefeld CD, Nicklas BJ, Wagenknecht LE, Saad MF, Bowden DW: Association of adipose tissue deposition and beta- 2 adrenergic receptor variants: the IRAS family study. Int J Obes 2005, 29(5):449-457.

36. Ehrenborg E, Skogsberg J, Ruotolo G, Large V, Eriksson P, Arner P, Hamsten A: The Q/E27 polymorphism in the beta2-adrenoceptor gene is associated with increased body weight and dyslipoproteinaemia involving triglyceride-rich lipoproteins. J Intern Med 2000, 247(6):651-656.

37. Carlsson M, Orho-Melander M, Hedenbro J, Groop LC: Common variants in the beta2-(Gln27Glu) and beta3-(Trp64Arg)-adrenoceptor genes are associated with elevated serum NEFA concentrations and type II diabetes. Diabetologia 2001, 44(5):629-636.

38. Heckbert SR, Hindorff LA, Edwards KL, Psaty BM, Lumley T, Siscovick DS, Tang Z, Durda JP, Kronmal RA, Tracy RP: Beta2-adrenergic receptor 
polymorphisms and risk of incident cardiovascular events in the elderly. Circulation 2003, 107(15):2021-2024.

39. Schürks M, Kurth T, Ridker PM, Buring JE, Zee RYL: Association between polymorphisms in the beta2-adrenergic receptor gene with myocardial infarction and ischaemic stroke in women. Thromb Haemost 2009, 101(2):351-358.

40. Zhao N, Liu X, Wang Y, Liu X, Li J, Yu L, Ma L, Wang S, Zhang H, Liu L, Zhao J, Wang $X$ : Association of inflammatory gene polymorphisms with ischemic stroke in a Chinese Han population. J Neuroinflammation. 2012, 9:162.

41. Lou Y, Liu J, Huang Y, Liu J, Wang Z, Liu Y, Li Z, Li Y, Xie Y, Wen S: A46G and C79G polymorphisms in the $\beta 2$-adrenergic receptor gene (ADRB2) and essential hypertension risk: a meta-analysis. Hypertens Res Off J Jpn Soc Hypertens 2010, 33(11):1114-1123.

42. Santulli G, Cipolletta E, Sorriento D, Del Giudice C, Anastasio A, Monaco S, Maione AS, Condorelli G, Puca A, Trimarco B, Illario M, laccarino G: CaMK4 Gene Deletion Induces Hypertension. J Am Heart Assoc 2012, 1(4):e001081.

43. Banack HR, Harper S, Kaufman JS: Coronary heart disease risk factors and mortality. JAMA 2012, 307:1137-1138. author reply 1138.

44. Canto JG, Kiefe Cl, Rogers WJ, Peterson ED, Frederick PD, French WJ, Gibson CM, Pollack CV Jr, Ornato JP, Zalenski RJ, Penney J, Tiefenbrunn AJ, Greenland P: Number of coronary heart disease risk factors and mortality in patients with first myocardial infarction. JAMA J Am Med Assoc 2011, 306(19):2120-2127.

45. Lanni F, Santulli G, Izzo R, Rubattu S, Zanda B, Volpe M, laccarino G, Trimarco B: The PI(A1/A2) polymorphism of glycoprotein Illa and cerebrovascular events in hypertension: increased risk of ischemic stroke in high-risk patients. J Hypertens 2007, 25(3):551-556.

46. Arribas S, Marín J, Ponte A, Balfagón G, Salaices M: Norepinephrine-induced relaxations in rat aorta mediated by endothelial beta adrenoceptors. Impairment by ageing and hypertension. J Pharmacol Exp Ther. 1994, 270(2):520-527.

47. Cotarlan V, Brofferio A, Gerhard GS, Chu X, Shirani J: Impact of $\beta(1)$ - and $\beta(2)$-adrenergic receptor gene single nucleotide polymorphisms on heart rate response to metoprolol prior to coronary computed tomographic angiography. Am J Cardiol 2013, 111(5):661-666.

doi:10.1186/1756-0500-7-396

Cite this article as: Kumar et al: Relationship between polymorphisms in beta -2 adrenergic receptor gene and ischemic stroke in North Indian Population: a hospital based case control study. BMC Research Notes 2014 7:396.

\section{Submit your next manuscript to BioMed Central and take full advantage of:}

- Convenient online submission

- Thorough peer review

- No space constraints or color figure charges

- Immediate publication on acceptance

- Inclusion in PubMed, CAS, Scopus and Google Scholar

- Research which is freely available for redistribution 